\title{
Influence of Network Teaching On College Public Physical Education Teaching
}

\author{
Li Zhiqiang \\ Police and Sport Department \\ Jilin Police College \\ Jilin, China \\ 954247200@qq.com
}

\begin{abstract}
With the rapid development of computer network, a new teaching form, network teaching, which has the profound influence on college public physical education, has emerged in the teaching field. This article elaborates the present situation of college public physical education and the characteristics of network teaching, thinks about the model of college public physical education under the network teaching environment, advocates integrating the network teaching method into the college public physical education in order to promote the deeper integration of information technology and college physical education curriculum.
\end{abstract}

Key words- Network Teaching; Public Physical Education; Teaching; Influence

\section{INTRODUCTION}

College public physical education is an indispensable and important part of higher education. In our country the school physical education has basically taken the movement technique teaching as the main content, the mastery of movement technique as the main mission of physical education, and the sport performance as the basis to the evaluate the result of the physical education for a long time. We continually take the competitive sports events from primary school to university. In many schools, teachers teach physical education as the quality class or physical ability class, and the teaching content has no interest or entertainment, so students are not interested in physical education, and they just learn passively. With the development of information technology, network teaching has stepped into classroom. Because of the open and the novelty characteristics, the network teaching may provide lots of interesting sport events and many matches of competitive sports for the students to stimulate their fitness consciousness and inject new vigor into traditional teaching. So, we can say that the presence of network teaching provides the possibility to change the traditional public physical education teaching model, and it provides the new opportunities and challenges for our college public physical educators as well. This article tries to make up for the deficiency of the traditional public physical education teaching by taking advantage of network teaching, in order to improve the teaching effectiveness of college public physical education.

\section{The Present Physical Condition of College Students AND COLlEge PUBlic Physical EdUCATION}

\section{A. The Present Physical Condition of College Students}

From 1985 to now, our country has made 5 times of large-scale health tests on students' physical condition. The longitudinal comparison on the statistics of those physical health tests shows that the physical condition of students in our country continued sliding down in the past 23 years. The result of the physical test in 2005 shows that the physical quality of the urban and rural students from 7 years old to 12 years old in our country, including speed, force, stamina, flexibility, explosive force, etc. has obviously declined in comparison with the result of physical health test in 1985 , especially the result of $50 \mathrm{~m} \times 8$ shuttle run, $1000 \mathrm{~m}$ run and $800 \mathrm{~m}$ run which can reflect the stamina quality has a large rate of decline. The average result of $1000 \mathrm{~m}$ run and 800 run of high school male students and female students from 13 years old to 18 years old separately decreased by 9.6s and 12.6s, and that result of college male students and female students from 19 years old to 23 years old separately decreased by 20.0s and 15.1s. Those statistics are worth us pondering on the school physical education and teaching reform in these years.

B. Present Situation of College Public Physical Education

The college physical education is following the traditional teaching model which has the deep brand of competitive sports. The students always learn for learning, and the present situation of education is not optimistic. With the deepening of basic education reform and the spreading of quality education, the college public physical education in the soil of Reform and Open is growing very fast, and it brings many new ideas into college physical education such as "happy sport”, “optional teaching”, etc. Some scholars think that as one part of the lifelong sport, school physical education takes sport as the ultimate aim, makes the people feel happiness in the sport and takes it as the lifelong goal; there are still some scholars think that the students shall learn and do sports independently according to the level and the ability of the students themselves, fully understand the relationship between sport and themselves, enjoy the happiness of physical education, love sport, form the habit and even make it as the lifelong goal. With the maturation of those ideas, the guiding idea of college physical education has changed correspondingly. The colleges independently reform the teaching, for example, some 
colleges implement the two-year optional physical education teaching; some colleges implement general education in the first year and implement the "three selfselections" optional teaching model in the second year that the students can choice the curriculum contents, the teachers and the schedules by themselves. According to my research, in Henan Province, because of the present situation of teachers and field, many schools implement "three selfselections t" teaching model in the second year, and those colleges widely spread the phenomenon of the students concentrate on some certain sports events excessively, which makes the teacher and the field can not meet the demand and the college public physical education return to the "shepherd type" teaching model. The result of implementation of "three self-selections" teaching model is not satisfactory, and we didn't achieve the anticipated goal.

\section{The Drawbacks of Traditional College Public Physical EducATION TEACHING MODEL}

\section{A. The Teacher's Specialties and Preference Influences the Selection of the Textbook}

The traditional college public physical education teaching model means the teacher teaching acts as the major and the student learning acts as the minor; in other words, the teacher explains and demonstrates, and the student fellows and exercises without relevant video material in class, which requires the teacher to have very high skill level and the excellent demonstrating ability, otherwise, it is very hard for the teacher to demonstrate properly. In addition, the teacher would like to arrange more contents that he likes and is good at when he establishes the teaching plan, which makes the singleness, simplification, lacking of systematization and scientificalness of sports events teaching.

\section{B. The Difficulty of Demonstrating the Movement Technique and the Single Teaching Method Influences Teaching Process and Student's Learning Interest}

For a long time, the traditional college public physical education teaching never escapes from the strange circle of competitive sports technique teaching, it still takes movement technique as the main learning content, and takes the sport performance as the main basis to evaluate the physical education result. In addition, by the influence of exam-oriented education, the students' movement techniques are uneven and the foundations are very weak. The teachers overemphasize the movement technique teaching, but it is very difficult for the students to see the movement occurs in a moment clearly and built the complete motion representation quickly without the supporting educational instruments, which leads to the students' losing the interest of the learning content.
IV. The Advantage of Network Teaching and the Starting Point of College Public Physical EDUCATION

\section{A. The Concept of Network Teaching}

The network teaching we said is the new learning environment created by the using of the characteristic and resource of network, it relies on the computer network, takes the internet as the teaching transmission system, is not limited by the fixed teaching time schedule or teaching location, transmits teaching content to the learner, and it is the learning activity to realize the goal of the education more effectively. There are many differences between the traditional teaching and the network teaching. The idea of network teaching indicates its strong vitality.

\section{B. The Characteristic and the Advantage of Network Teaching}

1) The Flexibility of the Teaching Time Schedule and the Openness of the Teaching Content

According to the digital technology and the multimedia technology, the network teaching makes the learner not be limited any more by the fixed teaching time schedule or the teaching location of the traditional teaching. The learner can accept education in any convenient time and allocate his time better. The teaching method of traditional teaching model means the teacher teaches the content determined by the textbook and the students accept it passively. So the network teaching is the teaching model which changes the method of teacher's controlling to the teaching content to the method of student's controlling to the learning content, and mobilizes their enthusiasm and activeness.

2) The Rich Teaching Resource and the Enlargement of the Communication Range

The major characteristic of network teaching is its rich teaching resource from which the students can accept lots of learning information, which makes the vision of self-study not be limited in the textbook. Meanwhile, the network teaching provides the technical platform for the communication between the students and the relevant professionals, which makes learning not the process of selfreclusive any more. Not only can the teachers and the students solve the problems about the content and the timeliness of information during the teaching process, they can get the match actions and the quality courses in each school to guide students' learning.

\section{The Network Teaching and the Starting Point of College Public Physical Education}

Now, every college has campus network. During the teaching process, the students try to use the campus network to study independently with the carrier of local area network and the channel of internet to get resource by combining with the reality of college public physical education on the basis of the basic information technology. For example, the basic knowledge of athletics, ball games, swimming, etc, provides very good starting point for CAI and network teaching. The students can watch the qualified CAI 
courseware and enjoy the vivid animation and the favorable audiovisual effect by network teaching, which enhances the students' understanding of multimedia technology and motion representation, and it has certain promotion effect on the teaching of athletics, ball games, aerobics, swimming, etc.

\section{THE APPlication OF NETWORK TEACHING IN College Public Physical EducAtion}

\section{A. The Network Teaching Can Enrich Teaching Methods and the Content}

Traditional college public physical education mainly takes speaking and demonstration as the teaching method, and the demonstration is the major method. But, because of the reason of teacher's quality, age, etc, the teacher's demonstration is often not standard and even wrong, which is very difficult to make the student built the complete motion concept or create the motion representation in mind effectively. Just as the bar-crossing action of high jump, because the slow demonstration can not complete the action effectively, the students just can observe from one angle, which is pretty difficult for the beginner. But network teaching can combine and provide a great number of words, photos of great athletes' technical movements, matches videos, flashes and sounds to every audience. So, every student can watch the movement of the greatest athlete and the student's idol, and watch from many angles, in slow speed and repeatedly, which makes them built the right motion representation from the beginning and discards the disadvantage of the traditional teacher's demonstration. Therefore, the network teaching enriches the method and the content of public physical education.

\section{B. Network Teaching Can Renew the Knowledge of Public Physical Education in Time}

In nowadays society, the update rate of knowledge is much higher. In the traditional college public physical education teaching, lots of teachers' teaching plans keep invariable for many years. The students are being imparted the knowledge which is obsolete, which makes the students have no interest in the learning content. Especially some emerging sports events, the teachers have no understanding about them. But with the presence of network teaching, the teachers and students can easily get the knowledge they need from internet and cultivate the interest and the ability of physical education by the using of network teaching.

\section{The Network Teaching Can Make College Students Get Inexpensive Physical Fitness Guide}

College public physical education is the last station for every student to join the society, which is pretty important to cultivate personal interest and ability of physical education. With the development of society, people's interest of exercising is becoming diversification gradually, to the learner who likes certain physical fitness exercise, if they can not get the physical fitness method from public physical education, their main puzzle is that they can not do it scientifically. The presence of network teaching can make the student search the physical fitness method and the solution of the problem from the internet by self and have the interactive teaching with the teacher and the famous coach on the other side to do scientific physical fitness exercise free for charge.

\section{CONCLUSIONS}

The using of network teaching with technology of computer network and multimedia can enrich the teaching method and content of traditional college public physical education, renew the knowledge of public physical education in time and make college students get inexpensive physical fitness guide. With the rapid development of information technology, network teaching is the future developing inexorable trend of education and the supplement and auxiliary to traditional public physical education, which has the profound influence on college public physical education.

\section{REFERENCES}

[1] Xiong Douyin. Network Age and Physical Education [J]. Journal of Sports and Science, 2001, (3).

[2] Li GuoFeng, Chu Zhe. The Research on the Teaching Assisting Management of Computer System in PE (Theorical Courses) of Universities__ Taking Jianghan University for Example [J]. Journal of Hubei Sports Science, 2008, (6)

[3] Zhu Baining, Wei Wei. The Research on College Physical Education's Fitness for the Development of Network Age in Our Country [J]. Zhejiang Sport Science, 2001, (2)

[4] Yang Lin, Niu Xuesong. The Present Situation and Future Development of Multi-media and Teaching Aids in University Sport Classes [J]. Journal of Shenyang Sport University, 2006, (3). 